\title{
IMPROVING STUDENTS' ORAL PRESENTATION PERFORMANCE THROUGH THE USE OF VISUAL MEDIA IN SMALL GROUP DISCUSSION
}

\author{
Audi Yundayani \\ Sekolah Tinggi Keguaran Ilmu Pendidikan (STKIP) Kusuma Negara, Jakarta, Indonesia \\ Email: audi_yundayani@stkipkusumanegara.ac.id
}

\section{Dian Kardijan}

University of Siliwangi, Tasikmalaya, Indonesia

Email: diankardijan@unsil.ac.id

APA Citation: Yundayani, Audi \& Kardijan, Dian..(2018). Improving Students' Oral Presentation Performance Through the Use of Visual Media in Small Group Discussion. Journal of English Language and literature, 3(2), 103-114.doi: 10.37110/jell.v3i2.55.

\begin{abstract}
Oral presentation as a part of academic speaking is required by the students in university level. However, students having problem in perform it due to lack of self confidence and lack of ideas to be presented. The aim of the research is to improve students' oral presentation performance by using visual media in small group discussion at STKIP Kusumanegara. The research method is a action research to show visual media using in solving students' oral presentation problem. Techniques for data collection are through observation, speaking test, interview, and documentation. The result of the research shows significant improvement in student' oral presentation performance. Through small group discussion, visual media using can support students to emerge several ideas during the oral presentation. Due to media support, students are being able to overcome their speaking anxiety. By the end, the result showed that visual media using through small group discussion can be an alternative way to improve students' oral presentation performance.
\end{abstract}

Keywords: oral presentation performance, visual media, small group discussion

\section{INTRODUCTION}

Speaking for academic purposes is used in describing spoken language in various academic field including oral presentation ability. Students in university level require oral presentation ability in academic field to communicate their thinking, ideas and opinion. As speaking ability, oral 
presentation performance can be seen as a productive skill which involves using speech to express meaning to other people (Spratt et. al., 2005). It is important to develop students' oral presentation skill that focus on delivering the message, not only on the form of their utterances.

Preliminary research showed that students having some difficulties in performing their oral presentation abilities. The problem was not only about the lack of vocabulary and grammar mastery, but also the lack of students' self confidence as the biggest one. The findings was strengthened by students' obstacle in practicing their speaking skills, focus on oral presentation performance. Most of the students did not believe themselves when they must speak English in front of others. They were afraid in making mistakes. They were not sure that they can deliver their speech in proper way because they can't trust their abilities in speaking. These plight caused students' low motivation to take part in the speaking class.

The above conditions should be overcame through the suitable teaching techniques including the media which are suitable with students' requirement. It is important for the teachers to find and use the appropriate media that can attract students' attention to realize the important of improving their speaking performance. The teaching techniques and media should encourage the students to practice and perform their oral presentation ability.

Visual media is a tool that can be used in learning process. It can be seen as the expression to describe things like movies, paintings, photographs and so on. It can be anything that is viewed in order to get its intended effect. Many people believe that visual media can attract students' attention in developing their speaking performance. The visual media can support students to deliver the message when performing their oral presentations. Through the picture, the painting, the photographs, the slide and so on, the audience can be easier to understand the content of students' speech. Hamzah (1985) stengthened by stating that picture, as one of the visual media, is the easiest aid to be used in learning process because it gives a concrete description about the problem described. Visual mediamake people grasp the idea or information clearly. Okada et. al. (2017) believed that students' presentation skills can be improved through video-recorded that shows students' strengths and weaknesses. By watching the video-recorded, students are able to evaluate their performace and it can be as a base to improve their weaknesses. The Okada's statement showed the 
advantageous of visual media in improning language performance.

It is important to choose the suitable teaching teachnique to be applied in using the visual media. Small group discussion technique can be the alternative. By dividing the classroom into small groups that consist of 2-4 students, teachers can provide the task and ask the students to solve it. Kindsvatter (1996) stated that a small group discussion dividing the large classroom into small group of students to achieve specific objectives. It permits students to assume more responsibility for their own learning. Students are able to develop social and leadership skill and become involved in learning process.

Students in university level require the oral presentation ability in expressing and conveying their ideas. As a part of English for academic purposes (EAP) skill, oral presentations ability requires not only vocabulary and grammar mastery but it also depends on students' knowledge and self confidence in delivering the massage. This oral presentation ability tend to be seen as communication skill, than a language skill.

De Grez, et. al., (2009) stated that instructional studies of oral presentation skill has not been established and the theory is limited. However, one of the expert,Price (1977), identified stages in oral presentation, 1) general introduction;

2) statement of intention; 3) information in detail; 4) conclusion; 5) invitation to discuss. In addition De grez, et. al., (2009) argued that students' presentations should be evaluated according to presentation criteria that focus on content and delivery. It can be evaluated clearly through the quality of introduction, structure, and conclusion as the content criteria and for the delivery or the performance criteria can be seen from the eye contact, vocal delivery, enthusiasim, interaction with audience and gestures.

Visual media can be presented in the form of blackboard drawing, wall pictures, chart, flashcard, magazine, projected slide and so on. It can be used in facilitating students' oral presentation performance and possible to make students' oral presentation performance more interesting. As the result the students' motivation and self confidence will increase. They can perform their presentation firmly.

Small group discussions involve the ability to present ideas verbally, engage in discussion, motivate group members to speak, respond to comments, defend or clarify one's stance or opinions and fend off interruption. Those abilities are essential for learning process in academic field in order to develop the students' knowledge and ideas 


\section{Audi Yundayani \& Dian Kardijan.}

Improving Students' Oral Presentation Performance Through the Use of Visual Media in Small Group Discussion

(Rendle-Short, 2006; Bligh, 2000).Small group discussions should be in real time listening attentively noting speech sounds, grammar in speaking, group interaction, gestures, developing ideas, proper degree of formality and appropriate vocabulary choices.

In applying small group discussion, students can change their thinking by interaction with others. Students are able to solve the problem and explore their experience in presenting their ideasby doing the discussion and as the consequences the class will be more active because the students push themselves to understand the information and to retrun it back.

\section{METHODS}

In order to reach the aim of the research, action research method was applied. Action research in education is a form of applied research whose rimary purpose is to increase the quality, impact, and justice of education professionals' practice (Gall, et.al., 2007). The data was taken from students and strengthened by the teachers as collaborator. There were stages of action research (Glanz, 1998), 1) selecting a focus; 2) taking action; 3) collecting data; 4) analyzing and interpreting the data; 5) continuing or modifying action; 6) reflection; 7) reporting action research. The collected data was reducted and presented. The data was collected through observation, interview and test. The qualitative data was strengthened by quantitative data taken from the result of students' oral presentation performance.

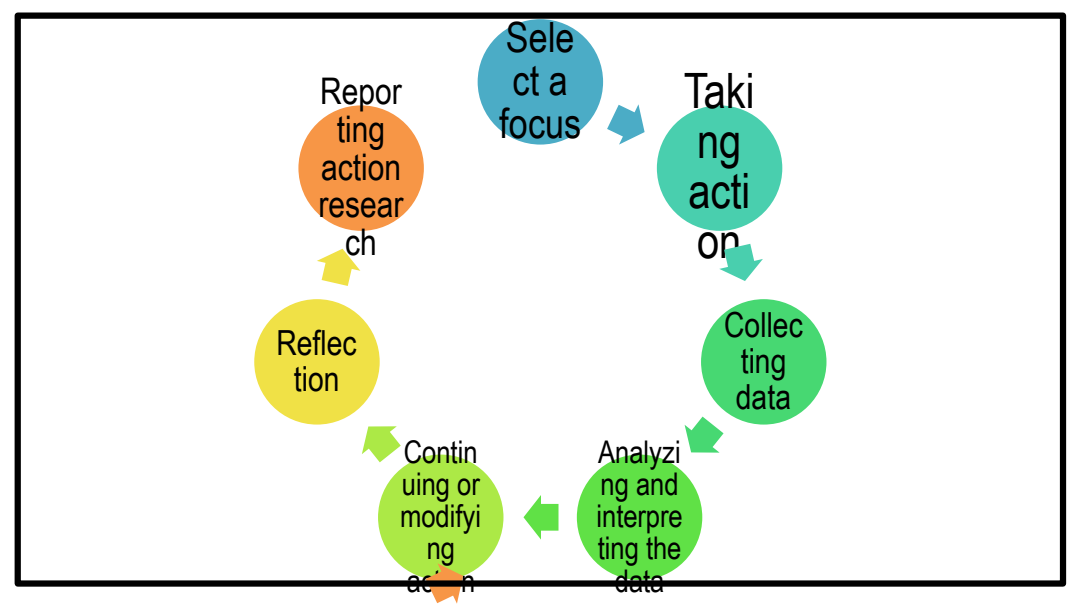

Figure 1. Stages of Action Research (Glanz, 1998) 


\section{FINDINGS AND DISCUSSION}

The findings of the research can be described as below.

\begin{tabular}{|c|c|c|}
\hline No & Stages & Result \\
\hline 1 & Select a focus & $\begin{array}{l}\text { Overcome students' problem inoral } \\
\text { presentation performance by using visual } \\
\text { mediain small group discussion }\end{array}$ \\
\hline 2 & $\begin{array}{l}\text { Taking action (cycle } \\
\text { 1) }\end{array}$ & $\begin{array}{l}\text { - During the classroom action research, the } \\
\text { researcher acting as the English teacher. } \\
\text { - Before starting the learning process, teacher } \\
\text { prepared all the learning components in the } \\
\text { form of syllabus, lesson plan, material, media } \\
\text { and evaluation instrument. } \\
\text { - Teacher started the class by checking the } \\
\text { attendance and continued by making the } \\
\text { students into small groups. } \\
\text { - Students were asked to choose the theme of } \\
\text { the problem that will be discussed. } \\
\text { - By turns every group presented the problem } \\
\text { and the solution as the result of their } \\
\text { discussion. } \\
\text { - They allowed to use anykind of visual media. } \\
\text { - The evaluation of oral presentation } \\
\text { performance was done during the learning } \\
\text { process, including the test. }\end{array}$ \\
\hline 3 & Collecting data & $\begin{array}{l}\text { Observation : Most of students was difficult to } \\
\text { present their ideas eventhough they used the } \\
\text { visual media. They could not deliver their } \\
\text { messages firmly and the audiences were } \\
\text { difficult to understand. Most of the students still } \\
\text { having lack of self confidence. In doing oral } \\
\text { presentations, the students prefered to use } \\
\text { picture as visual media. Discussion was done } \\
\text { through students' mother tongue. } \\
\text { Interview : Many students thought that } \\
\text { speaking was difficult. They were afraid in } \\
\text { making mistake. They realized that they have } \\
\text { problem in vocabulary mastery. They were }\end{array}$ \\
\hline
\end{tabular}


Audi Yundayani \& Dian Kardijan.

Improving Students' Oral Presentation Performance Through the Use of Visual Media in Small Group Discussion

\begin{tabular}{|c|c|c|}
\hline No & Stages & Result \\
\hline & & $\begin{array}{l}\text { confuse in choosing the suitable visual media. } \\
\text { The result of speaking test : The average score } \\
\text { is } 65.23\end{array}$ \\
\hline 4 & $\begin{array}{l}\text { Analyzing and } \\
\text { interpreting the data }\end{array}$ & $\begin{array}{l}\text { The data showed that students' oral } \\
\text { presentation performance was still low and } \\
\text { have not catched up the expectation. The } \\
\text { problem related with students' self confidence } \\
\text { that having the impact with their performance. } \\
\text { They have not explored many kind of visual } \\
\text { media that can be used. They were not serious } \\
\text { in doing the discussion. }\end{array}$ \\
\hline 5 & $\begin{array}{l}\text { Continuing or } \\
\text { modifying the action }\end{array}$ & $\begin{array}{l}\text { Teacher decided to continue the action by } \\
\text { modifying the treatment to the students. }\end{array}$ \\
\hline 6 & $\begin{array}{l}\text { Taking action (cycle } \\
\text { 2) }\end{array}$ & $\begin{array}{l}\text { - The result of cycle } 1 \text { was the base to improve } \\
\text { the learning process in the cycle } 2 \text {. } \\
\text { - Before starting the learning process, } \\
\text { researcher prepared all the learning } \\
\text { components in the form of syllabus, lesson } \\
\text { plan, material, media and evaluation } \\
\text { instrument. } \\
\text { - Researcher started the class by checking the } \\
\text { attendance. } \\
\text { - In the cycle 2, researcher applied ice } \\
\text { breaking before starting the lesson to make } \\
\text { the classroom environment more relax. } \\
\text { - To stimulate the students and to recall their } \\
\text { schemata, questions were given. } \\
\text { - After that, the students were asked to make } \\
\text { their own groups. } \\
\text { - Researcher gave the topic of the problem that } \\
\text { will be discussed. } \\
\text { - Related vocabularies with the topic were } \\
\text { - Bresented and discussed. } \\
\text { and the solution as the result of their } \\
\text { discussion. } \\
\text { - They allowed to use anykind of visual media. } \\
\text { - The evaluation of oral presentation } \\
\text { performance was done during the learning }\end{array}$ \\
\hline
\end{tabular}




\begin{tabular}{|c|c|c|}
\hline No & Stages & Result \\
\hline & & process, including the test. \\
\hline \multirow{3}{*}{7} & & $\begin{array}{l}\text { Observation : Most of students seemed more } \\
\text { relax in presenting their ideas. The various } \\
\text { visual media have been started to be used, not } \\
\text { only by picture. They could deliver their } \\
\text { messages firmly, eventhough sometimes they } \\
\text { lost the English words and used Indonesian } \\
\text { language. They started to make interaction with } \\
\text { the audiences by eye contact and body } \\
\text { positioning. Some students still having lack of } \\
\text { self confidence but they tried to handle it by } \\
\text { keep talking. They still did not use English } \\
\text { when doing the discussion. }\end{array}$ \\
\hline & Collecting data & $\begin{array}{l}\text { Interview : Many students started to have self } \\
\text { confidence. They felt more relax when the } \\
\text { teacher started the class through ice breaking. } \\
\text { The questions that were given by the teacher } \\
\text { helped them to recall their memory. The } \\
\text { presented vocabulary related with the topic } \\
\text { made them easy to deliver the ideas when doing } \\
\text { oral presentation. They felt easier in doing the } \\
\text { discussion when the teacher provided the topic } \\
\text { or the theme that should be discussed. They } \\
\text { tried to explore many kinds of visual media and } \\
\text { they realized that visual media can be anything } \\
\text { which are able to support their oral } \\
\text { presentations. Using English when doing } \\
\text { discussion was still difficult for them. }\end{array}$ \\
\hline & & $\begin{array}{l}\text { The result of speaking test } \text { : The average score } \\
\text { is } 74.43\end{array}$ \\
\hline 8 & $\begin{array}{l}\text { Analyzing and } \\
\text { interpreting the data }\end{array}$ & $\begin{array}{l}\text { The data showed that students' self confidence } \\
\text { in oral presentations improved. They required } \\
\text { more than suitable media and teaching } \\
\text { technique. The most important is teacher's role } \\
\text { as fasilitator and manager.Teacher must } \\
\text { understand students' needs. It is important to } \\
\text { design good teaching athmosphere that make } \\
\text { the students feel comfort. }\end{array}$ \\
\hline
\end{tabular}


Audi Yundayani \& Dian Kardijan.

Improving Students' Oral Presentation Performance Through the Use of Visual Media in Small Group Discussion

\begin{tabular}{|c|c|c|}
\hline No & Stages & Result \\
\hline 9 & $\begin{array}{l}\text { Continuing or } \\
\text { modifying the action }\end{array}$ & $\begin{array}{l}\text { Teacher decided to continue the action by } \\
\text { giving the same treatment to the students. }\end{array}$ \\
\hline 10 & $\begin{array}{l}\text { Taking action (cycle } \\
\text { 3) }\end{array}$ & $\begin{array}{l}\text { - The result of cycle } 2 \text { was the base to improve } \\
\text { the learning process in the cycle } 3 \text {. } \\
\text { - All the steps of learning process in the cycle } 2 \\
\text { was applied in the cycle } 3 \text {. } \\
\text { - The different was teacher decided to use slide } \\
\text { presentation as the visual media. In addition, } \\
\text { the students applied peer evaluation by giving } \\
\text { comment or suggestion. }\end{array}$ \\
\hline \multirow[t]{3}{*}{11} & \multirow[t]{3}{*}{ Collecting data } & $\begin{array}{l}\text { Observation : Most of students seemed more } \\
\text { relax in presenting their ideas. They could } \\
\text { deliver their messages firmly. They started to } \\
\text { make interaction with the audiences by eye } \\
\text { contact and body positioning. } \\
\text { Peer evaluation gave positive impact in } \\
\text { performing their oral presentation. They pushed } \\
\text { themselves to give their best performance. }\end{array}$ \\
\hline & & $\begin{array}{l}\text { Interview : Many students believed that using } \\
\text { visual media in small group discussion can } \\
\text { improve their oral presentation performance. }\end{array}$ \\
\hline & & $\begin{array}{l}\text { The result of speaking test : The average score } \\
\text { is } 81.40\end{array}$ \\
\hline 12 & $\begin{array}{l}\text { Analyzing and } \\
\text { interpreting the data }\end{array}$ & $\begin{array}{l}\text { Overall the data showed that students' self } \\
\text { confidence in oral presentations improved from } \\
\text { cycle } 1 \text { to cycle } 3 \text {. Visual media and small } \\
\text { group discussion are effective to be applied in } \\
\text { overcome students' difficulty in oral } \\
\text { presentation. }\end{array}$ \\
\hline \multirow[b]{2}{*}{13} & \multirow[b]{2}{*}{ Reflection } & $\begin{array}{l}\text { From cycle } 1 \text { to cycle } 3 \text {, researcher done the } \\
\text { reflection together with the collaborator. }\end{array}$ \\
\hline & & $\begin{array}{l}\text { In the cycle } 1 \text { : Students still confused and lack } \\
\text { of self confidence because of less teachers' } \\
\text { support in teaching process. Teachers only gave } \\
\text { the instruction without giving the clue or any }\end{array}$ \\
\hline
\end{tabular}




\begin{tabular}{|c|c|c|}
\hline No & Stages & Result \\
\hline & & $\begin{array}{l}\text { treatment. This findings were improved in the } \\
\text { cycle } 2 \text {. } \\
\text { In the cycle } 2 \text { : Teacher' roles gave positive } \\
\text { impact to students' performance in oral } \\
\text { presentation through building positive teaching } \\
\text { environment, doing ice breaking, giving a topic, } \\
\text { introducing related vocabularies and advicing } \\
\text { the alternative of visual media. } \\
\text { In the cycle } 3 \text { : The treatment in cycle } 2 \text { still } \\
\text { applied in cycle } 3 \text {. To strengthen the students' } \\
\text { improvement, teacher applied peer evaluation } \\
\text { and it worked. The treatment increased } \\
\text { students' performance in doing oral } \\
\text { presentation. }\end{array}$ \\
\hline 14 & $\begin{array}{l}\text { Reporting action } \\
\text { research }\end{array}$ & $\begin{array}{l}\text { Students' oral presentation performance can be } \\
\text { improved through visual media using in small } \\
\text { group discussion technique. }\end{array}$ \\
\hline
\end{tabular}

The findings showed us that students' difficulties in performing oral presentation can be solved through visual media using in small group discussion. As the productive skill, oral presentation performance should be done naturally. It strengthened by Brown, et.al. (2004) that define speaking as a productive skill that can be directly and empirically observed and colored by the accuracy and effectiveness of listening skill. It can be concluded that speaking is an activity which involves two or more people. They are both the listener and speaker who make contribution by using effective language to communicate successfully. Fulcher (2003) stated that a speaker must employ language effectively and appropriately in orderto communicate to a listener.

Many students believe that speaking skill is difficult to be mastered, not only because of lack vocabulary or grammar mastery but it because of lack of self confidence. Luama (2004) believed that speaking is also the most difficult language skillto assess reliablybecause it is usually judged during a face to face interactionin real time, between an interlocutor and a locutor. Speaking skill can be seen as an interactive 
process that requires the ability to corporatethe management of taking turns. It happens in oral presentation performance. The audience can judge the speaker's performance directly without considering the message that will be delivered, the purpose of presentation and the speaker's condition and situation.

Small group discussion can be seen as a group work that students can do interaction by practicing the oral fluency (Ur, 2000). Small group discussion give the students opportunity to interact, question, and elaborate with peers morefrequently than they have in a teacher-centered environment. The observation during cycle 1 to cycle 3, students' involvement in discussion getting more active. They pushed themselves to be a part of the discussion.

The research findings showed the students' improvement can be achieved if the learning process was done in good and low anxiety situation, fun, communicatively, and not oppressive. The use of visual media can overcome their burden in oral presentation situation. The students stated that visual media using was an interestinglearning media where they could organize their presentation and participationusing their creative ways. Walberg (2008) strengthened by stating that students can give better speeches when they can organize their presentation in a variety of different ways, including sequentially, chronologically and thematically. Visual media can support students to emerge several ideas during the oral presentation.

The various visual media can be seen as the good media to help students to overcome speaking anxiety. Brown (1983) stated that media establishes condition which enable the students to acquire knowledge, skills, and attitude. Media are tools or the physical things used by the teacher to facilitate the instruction.

Visual media using can reduce thestudents' boredom and problem in oral presentation. They were not shy anymorebecause they speak to the big group. They were enthusiastic and encouraged togive oral presentation in front of the audience. They had reallife communication, authenticactivities, shared knowledge and meaningful learning.

\section{CONCLUSION}

Students' difficulties in performing oral presentation can be improved through visula media using in small group discussion. Through that treatment, students are placed in a situation where they are encouraged to interact using the target language by providing the effective use of classroom 'speakingtime' in order to give the students greater opportunities for sharing ideas. 
It ismuch easier to do the oral presentation to a peer in a small-group than to do it in a whole class. However, some weaknesses appeared, 1) noisy classroom when every students were working in a group; 2) native language using when the teacher was not around; 3) lack of self confidence. Therefore, teachers should encourage the students to explore their oral presentation ability through any kind of teaching techniques and any media using based on students' interest and needs.

\section{BIBLIOGRAPHY}

Bligh, D.A. (2000). What's the point in discussion? Exeter: Intellect.

Brown, James W. \&Lewis Richard, B. (1983). $A v$ Instruction:Technology, Media, andMethods. New York: McGraw-Hill, Inc.

Brown, D., Rogers, J., \& Rogers, T. S. (2004). Doing second language research.

Oxford:Oxford

University Press.

De Grez, L., Valcke, M., \& Roozen, I. (2014). The differential impact of observational learning and practice based learning on the development of oral presentation skills in higher education. Higher Education Research and Development, 33, 256-271. Doi: 10.1080/07294360.2013.832155.
Fulcher, G. (2003). Testing second language speaking. London: Person Longman

Gall, et.al. (2007). Educational research. 8th Edition. Boston: Pearson Education, Inc.

Luama, S. (2004). Assessing speaking. Cambridge: Cambridge University Press.

Okada, Yasuko, et. all. (2017). Effects of Observing Model Video Presentations on Japanese EFL Learners' Oral Performance. Electronic Journal of Foreign Language Teaching, Vol. 14, No. 2, pp. 129-144.

Price, J. E. (1977). Study skills-with special reference to seminar strategies and one aspect of academic writing. In S. Holden (Ed.) English for Specific Purposes. London: MEP.

Rendle-Short, J. (2006). The academic presentation: Situated talk in action. Hamphire: Ashgate Publishing Limited.

Spratt, Mary, Alan Pulverness \&Melanie William. (2005).The Teaching Knowledge Test Course. Cambridge: Cambridge University Press.

Sulaiman, Amir Hamzah. (1985). Audio Visual Media. Jakarta: PT. Gramedia.

Ur, P. (2000). A course in language teaching: Practice and theory. Cambridge: CambridgeUniversity Press. 


\section{Audi Yundayani \& Dian Kardijan.}

Improving Students' Oral Presentation Performance Through the Use of Visual Media in Small Group Discussion

Walberg, H.J. (2008). English for

Open UniversityPress.

Communication. Philadelphia: 